\title{
Model-Driven Hyper content Module Development Picture and Picture for Personal Learning of Students with Special Needs
}

\author{
Maemunah Sa'diyah, Ibn Khaldun University Bogor, KH. Sholeh Iskandar KM. 02 Bogor City, \\ maemunah@fai.uika.ac.id \\ Mohammad Muhyidin Nurzaelani, Ibn Khaldun University Bogor, KH. Sholeh Iskandar KM. 02 Bogor City \\ Putri Ria Angelina, Ibn Khaldun University Bogor, KH. Sholeh Iskandar KM. 02 Bogor City \\ Yuggo Afrianto, Ibn Khaldun University Bogor, KH. Sholeh Iskandar KM. 02 Bogor City \\ Endin Mujahidin, Ibn Khaldun University Bogor, KH. Sholeh Iskandar KM. 02 Bogor City \\ Dedi Supriadi, Ibn Khaldun University Bogor, KH. Sholeh Iskandar KM. 02 Bogor City
}

\begin{abstract}
The system of education in the university should be friendy with the students with spesial needs. The system include the curriculum, methods, and also the material to make the students easier to understand the materials.one of innovation to help the students with special needs is make a hypercontent module for microteaching subject. The module developed by ADDIE model and helped the stundents improve their ability.
\end{abstract}

Keywords: ADDIE, Hyper content Module, Picture and Picture. Received: $15.11 .2020 \quad$ Accepted: $11.12 .2020 \quad$ Published: 16.01 .2021

\section{INTRODUCTION}

There is a law to student with Special Education and Special Services in Higher Education accordance Permenristek Dikti Number 46 of 2017. It shows that Indonesia has a serious attention to them. Students with special needs or persons with disabilities are those who experience disruptions / obstacles in carrying out certain activities so that they need special tools, environmental modifications or appropriate alternative techniques so that they can follow the learning optimally so that one day they can participate fully and productively in people's lives. Many people with special needs have high academic potential and motivation to continue their education to higher education level. Many of them succeeded despite having to go through a very heavy adjustment process. Some of them are even able to complete education programs up to the doctoral level.

Opportunities for people with special needs to attend education at the college level are increasingly wide open with the issuance of Law No. 8 of 2016 on Persons with Disabilities. The law is affirmed in article 10 Paragraph a: Persons with Disabilities are entitled to a quality education in education units of all types, pathways, and levels of education in an inclusive and special manner. Article 18: Every Person with Disabilities has the right to accessibility in article 40 Paragraph 1: "The Government and Local Government shall organize and/or facilitate education for Persons with Disabilities at every level, type, and level of education in accordance with his authority".

The obstacles and challenges of studying in college for students with special needs must be greater than the difficulties faced by ordinary students. In addition to the limited disability services units in universities, another cause is because not all lecturers understand the characteristics of students with special needs. Lecturers are required not only to know students with special needs, characteristics and special needs, but also required to develop innovation and creativity in learning so that all students including students with special needs can follow and succeed in meeting the learning targets set by lecturers. Therefore, innovative learning models are needed that can be applied to students with special needs in order to facilitate and serve students with special needs in order to actively participate in the learning process.

Students with Special Needs (SWSN) have problems in online learning specially practicum subject including micro teaching. The reviewer are form Islam Departmement in the Faculty of Islamic Studies of Islamic Religious Education Program is microteaching courses. The development of information and communication technology (ICT) has had an impact on the utilization of various learning materials (Nurzaelani, Septiani, \& Maimunah, 2020). Learning innovation in this course, develope of Hypercontent Learning Module based on Picture and Picture model. Suprijono (2009) said that images and images learning strategies use images as a learning medium, learning using Picture and Picture models will allow learners to know something concrete. Ngalimun (2016) said that Picture and Picture is 
the competency information of real treats, presentation materials, impressions of activities related to the material, students sorting the images so systematically, teachers confirm the order of images, teachers embed concepts precisely in teaching materials, inference, evaluation and reflection. Pradina and Hastuti (2017) said the Picture and Picture model can be used to study all subjects.

\section{RESEARCH METHODS}

This research is a development research that adopts ADDIE model(Analysis, Design, Development, Implementation, Evaluation). This model is one of the suitable and effective models for use in the development of learning modules. According to Branch (2009) "the simplicity of the ADDIE concept combined with some clues continues to prove its effectiveness".

The purpose of this research, to produce hypercontent module design based on picture and picture model for personal learning of students with special needs, then in this study only presented analysis and design stages of addie model. According to Milman and Kilbane (2013) "teachers can use ADDIE in whole or in part to help them develop more effective learning, units and teaching materials". The analysis stage in this study includes activities: (1) performance analysis; (2) analysis of student characteristics; (3) analysis of learning objectives; and (4) material analysis. The Design Stage of this research includes activities: (1) formulation of learning materials; (2) designing learning scenarios; and (3) the design of learning evaluation tools. (Cahyadi, 2019). Tegeh et al. (2015). The development phase includes the development and modification of the learning module, as well as the feasibility testing of the module. The implementation stage in this research is the implementation stage of the draft teaching materials that have been developed in learning for students with spesial need.

This research was carried out in the Islamic Religious Education study program of the Faculty of Islamic Religion Ibn Khaldun University in the 2020/2021 school year. The research data was taken from the study of documentation and filling in questionnaires by one of the students with special needs to be further analyzed using descriptive qualitative techniques. The results of the analysis became the basis for the creation of hypercontent modules based on picture and picture models in microteaching subjects.

\section{RESULTS}

This research found some results with ADDIE model to implementetaion the research. They are :

\section{Analysis Stage}

The first stage is to analyze the need for hypercontent module development based on picture and picture model microteaching courses. Analysis has the following stages:

\section{Performance analysis}

Student with special needs with autistic spectrum has problems include; ability to explore words, ability to making friend, ability in understanding text, ability to make sounds and performing motion and mimic innovations and limitations in conveying conversations / problems systematically. The student with special need show visual learning style whisch is easier to learn with visible materials, see the writing even at a glance, and also neat in appearance.

\section{Analysis of student characteristics}

Generally, students can follow learning with limited ability to receive lecture materials, the main difficulty in the material with a long enough narrative such as when having to tell an inspiring story related to lecture material, he is only able to convey the core points only. His critical ability was also very limited, this was evident when he was asked to comment on the issues offered. While creative ability began to develop when given directions and examples of the use of learning media to maximize achievement. Another visible characteristic is the ability to receive learning delivered with good visualization, this is related to the learning style of atudents with spesial needs that tends to be visual.

Some characteristics of Students with Special needs (SWSN:

1) SWSN is an avid learner who is disciplined in attending lectures

2) Have limited knowledge and skills from what the lecturer conveys, when quantified score almost on average at the value of 60 or simply enough.

3) Limited critical capabilities

4) Have a visually inclined learning style

5) Creative ability is good enough when you get directions 
SWSN with the skills described makes it possible to provide services or learning interventions that enable this SWSN to improve its knowledge and skills. One of the recommended ways is to increase student learning motivation by modifying learning in the form of visual directions both motionless images and audio visuals. This method can also be trained to SWSN in order to have the skills to present images and make video learning for the benefit of teaching plates both in the microteaching room and in school.

\section{Analysis of learning objectives}

The purpose of learning in this Microteaching course is that students are expected to have the following abilities (Usman, 2017):

1) Describe the meaning and urgency of microteaching learning ;

2) Describe the basic theory of Microteaching and Real Teaching learning ;

3) Analyzing the learning characteristics of Islamic Religious Education (PAI);

4) Teachers and students in learning as an important part of the teacher's code of conduct;

5) Implementing the five competencies of PAI teachers;

6) Explain the learning steps;

7) Practice basic teaching skills;

8) Practice PAI learning in Microteaching Laboratory independently;

9) Practice PAI learning in microteaching laboratories in collaboration;

10) Practice PAI learning in Schools/Madrasahs;

11) Provide an assessment of other people's learning practices;

12) Analyze the teaching skills;

13) Needs assesment

Competence of students with special needs developed by this research are number 1 to number 7 only. Based on the elaboration of the learning objectives, the competency map in microteaching courses is described as follows.

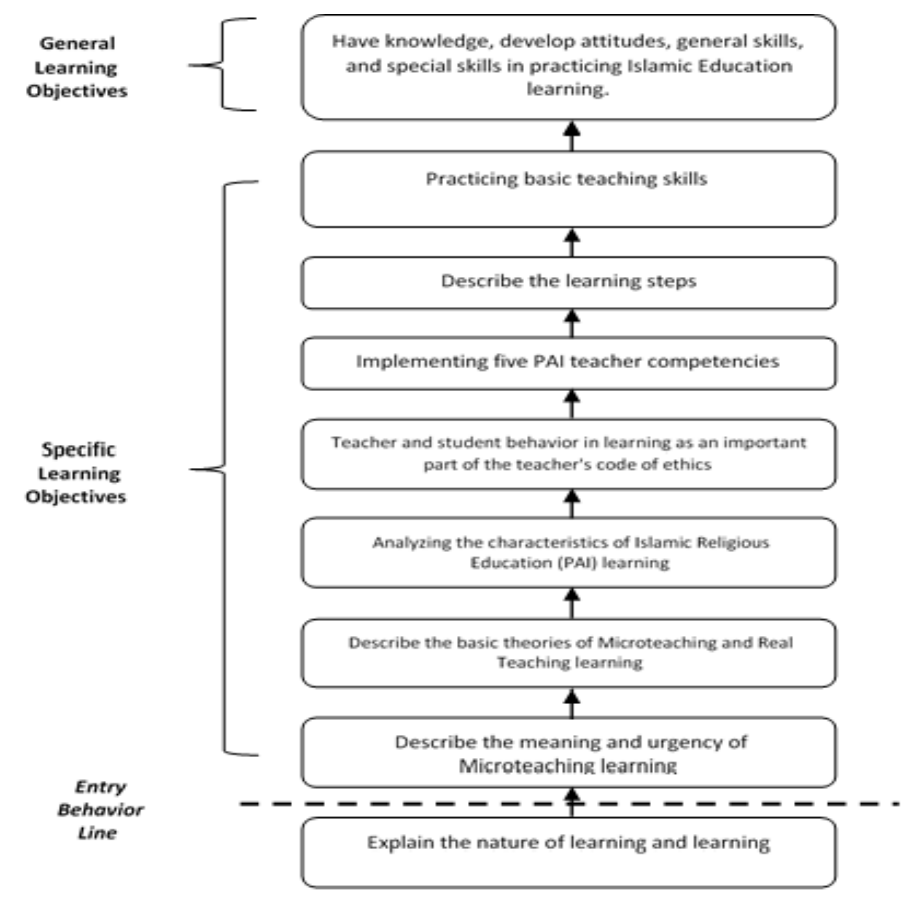

Figure 1. Microteaching Course Competency Map

\section{Material analysis}

Several materials will be presented in hypercontent modules based on picture and picture model hypercontet microteaching courses as follows: (1) Microteaching Theory, Real Teaching, Team Teaching, Peer Teaching; (2) PAI Learning; (3) Basic teaching skills; and (4) PAI learning practices.

\section{Design Stage}

The second stage of this research is the design stage which includes several activities as follows. (1) formulation of learning materials; (2) designing learning scenarios; and (3) the design of learning evaluation tools. 


\section{Formulation of learning materials}

The learning materials for the Microteaching course module are presented in the following image.

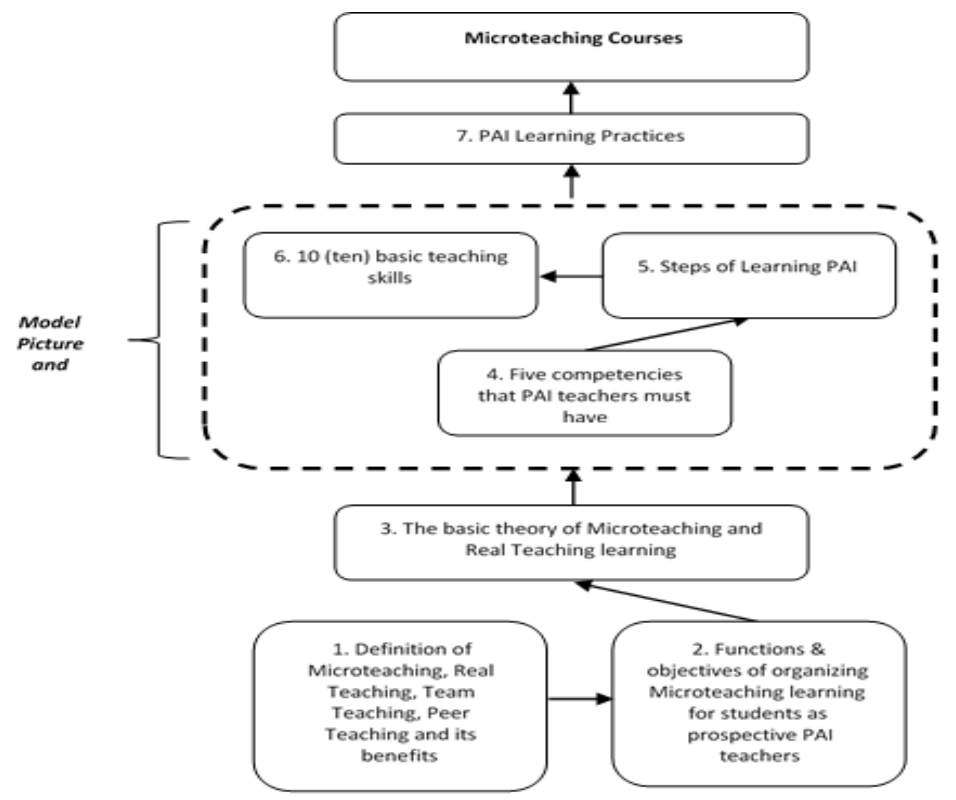

Figure 2. Microteaching Course Module Concept Map

The learning module will use hypercontentmedia, where the module is connected to other materials in the form of videos, presentation slides, and tasks that can be accessed online using hyperlinks and QR Code. In PAI learning characteristics material, five competencies that must be possessed by PAI teachers, PAI learning steps, and 10 (ten) basic teaching skills will be presented using a picture and picturemodel, which will be displayed images in the module in sequence and equipped with video as an example that can be accessed through hyperlinks and QR Code.

\section{Learning scenario design}

Learning scenarios are prepared in the Semester Learning Plan that contains the identity of courses and lecturers, learning achievements, sub-achievements of learning, description of courses, learning materials / subject matter, libraries used, learning media, forms and methods of learning, as well as assignments and assessments. Learning in microteaching courses will be carried out online in accordance with the current conditions where the covid-19 pandemic is still ongoing. Students will use modules that can be accessed through the Learning Management System (LMS), and the module can be used for self-learning, because in the module there is a hypercontent, where the module is connected with other learning content in the form of broadcast materials, learning videos, and tasks.

\section{Designing learning evaluation tools}

Evaluation of learning is carried out by oral test and PAI learning practice skills test assessed through teaching observation sheet instruments. Observation sheets are made in accordance with the practice carried out.

\section{Development Stage}

The development stage of this research is divided into several activities such as collection and development of learning materials both contained in modules and outside modules that can be accessed through modules (hypercontent), development of illustrations / images in accordance with picture and picture methods,development of learning evaluation, typing, editing, and setting lay out modules. The development stage is also carried out again after obtaining expert validation results, if there are revisions and inputs from experts. 


\section{MODUL PEMBELAJARAN MICROTEACHING}

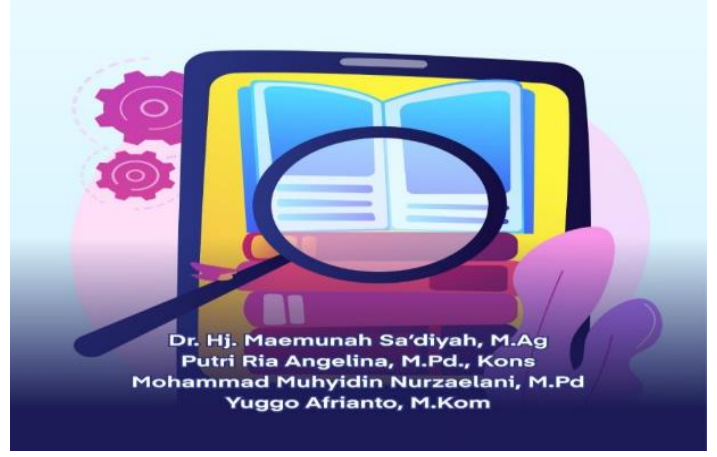

Figure 3. Micro Teaching Learning Module Cover

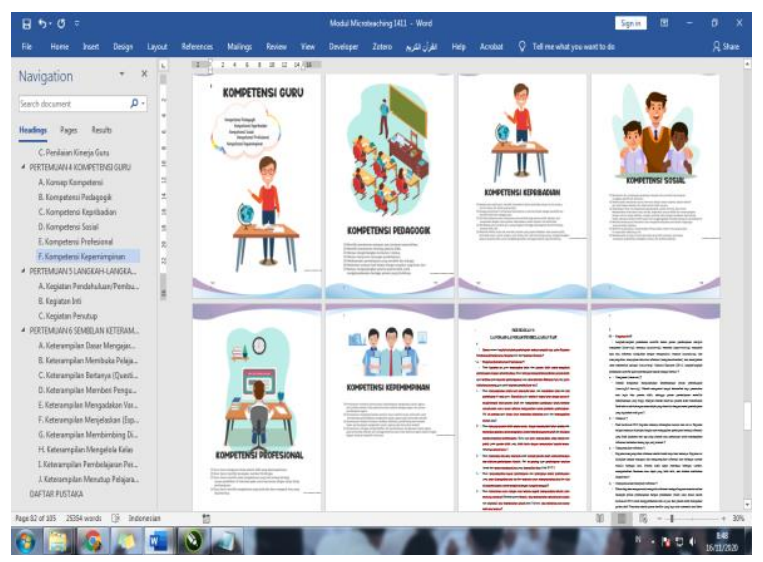

Figure 4. Micro Teaching Module Writing Process

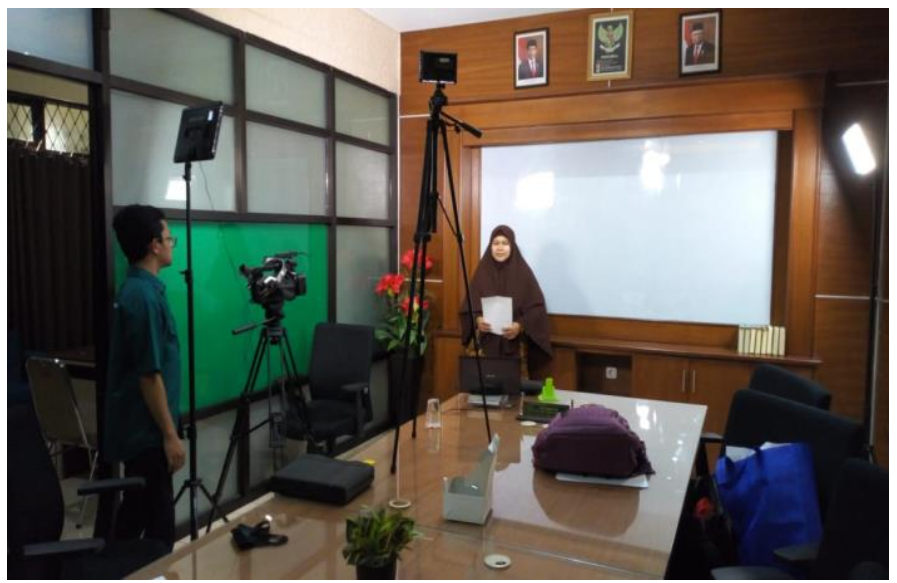

Figure 5. Micro Teaching Learning Video Development

Learning in Micro Teaching courses will be carried out online in accordance with the current conditions where the covid-19 pandemic is still ongoing. Students will use modules that can be accessed through the Learning Management System (LMS), and the module can be used for self-learning, because in the module there is Hypercontent, where the module is connected with other learning content in the form of broadcast materials, learning videos, and tasks. Modules are built based on Picture and Picture models designed to make it easier for students with special needs and students in general to understand learning. 


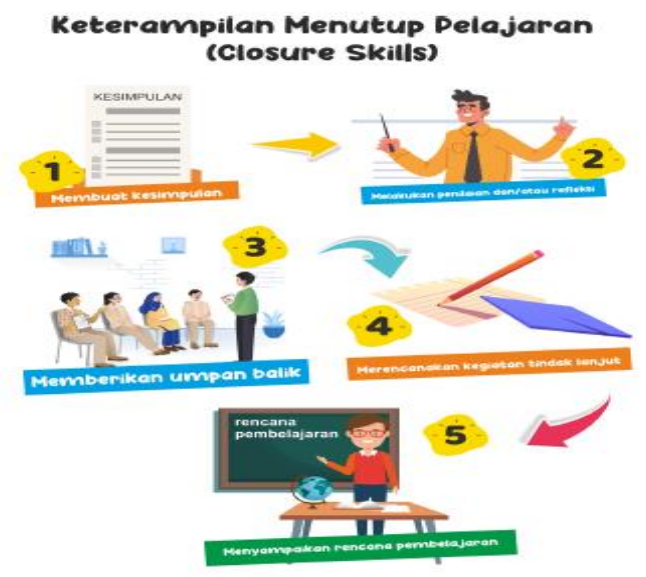

Figure 6. Examples of Application of Picture and Picture Models in Modules

Formativevaluation e is carried out in order to test the feasibility of learning modules. One to one trials were conducted to assess the feasibility of learning modules with 3 experts, namely: content experts, design experts and learning media, and linguists. Expert trials are carried out after the teaching materials are developed. The number of instrument items given to each expert and student is as follows:

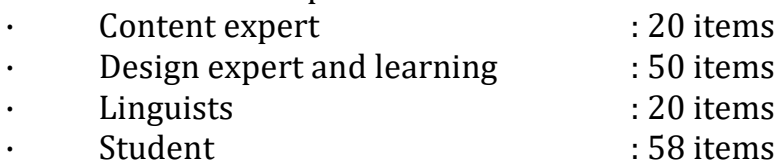

The feasibility test of teaching materials was carried out by distributing instruments in the form of questionnaires with 4 excellent answer options $=4$, good $=3$, less good $=2$, and very poor $=1$ to content experts as many as 20 points, design experts and learning media as many as 50 points, and linguists as much as 20 . Feasibility percentage assessment presented on Tabel 1.

Table 1. Percentage Eligibility

\begin{tabular}{|l|l|}
\hline Percentage Assessment & Interpretation \\
\hline $76-100 \%$ & Very Feasible \\
\hline $50-75 \%$ & Worth \\
\hline $26-50 \%$ & Enough \\
\hline$<26 \%$ & Less Worthy \\
\hline
\end{tabular}

Suharsimi Arikunto in Gian Dwi Oktiana (2015:63)

\section{Content Expert}

Validation of the feasibility of Hypercontent Module Micro Teaching Course Based on Picture and Picture model conducted by content experts, namely by conducting an assessment of the material presented contained in 20 instruments. Content experts also provide suggestions and opinions for the improvement of learning modules. The results of the assessment of learning modules by content experts are presented in table 2 below.

Table 2. Content Expert Assessment Results

\begin{tabular}{|l|l|l|l|}
\hline № & Statement & Value & Description \\
\hline 1 & $\begin{array}{l}\text { The content of the lesson materials has supported the } \\
\text { achievement of the General Learning Objectives (GLO). }\end{array}$ & 4 & Excellent \\
\hline 2 & $\begin{array}{l}\text { The subject matter includes all Specific Learning } \\
\text { Objectives (GLO). }\end{array}$ & 4 & Excellent \\
\hline 3 & $\begin{array}{l}\text { The description of the subject matter has supported the } \\
\text { achievement of each GLO. }\end{array}$ & 4 & Excellent \\
\hline
\end{tabular}




\begin{tabular}{|c|c|c|c|}
\hline 4 & $\begin{array}{l}\text { The breadth of the contents of the lesson material is } \\
\text { appropriate to achieve each GLO indicator. }\end{array}$ & 4 & Excellent \\
\hline 5 & $\begin{array}{l}\text { The depth of the content of the lesson materials has } \\
\text { supported the achievement of each GLO indicator. }\end{array}$ & 3 & Good \\
\hline 6 & $\begin{array}{l}\text { The subject matter and sub-subject matter have been } \\
\text { structured in an integrated manner to achieve GLO }\end{array}$ & 4 & Excellent \\
\hline 7 & $\begin{array}{l}\text { The subject matter for each GLO indicator has been } \\
\text { presented in a balanced manner. }\end{array}$ & 4 & Excellent \\
\hline 8 & $\begin{array}{l}\text { Subject matter can be learned according to the available } \\
\text { time allocation. }\end{array}$ & 3 & Good \\
\hline 9 & The truth of the concept can be accounted for. & 3 & Good \\
\hline 10 & The concepts presented are up-to-date. & 4 & Excellent \\
\hline 11 & $\begin{array}{l}\text { The concepts presented are still relevant to the present } \\
\text { situation. }\end{array}$ & 4 & Excellent \\
\hline 12 & The concept presented has been consistent. & 4 & Excellent \\
\hline 13 & $\begin{array}{l}\text { The material presented does not conflict with Rac, etjnic, } \\
\text { religion and State rules. }\end{array}$ & 4 & Excellent \\
\hline 14 & The concepts are organized systematically. & 4 & Excellent \\
\hline 15 & $\begin{array}{l}\text { The order of concepts makes it easy for students to } \\
\text { understand the concepts as a whole. }\end{array}$ & 3 & Good \\
\hline 16 & $\begin{array}{l}\text { The example presented is relevant to the concept to be } \\
\text { explained. }\end{array}$ & 3 & Good \\
\hline 17 & $\begin{array}{l}\text { The exercises presented are relevant to the concept to be } \\
\text { explained. }\end{array}$ & 4 & Excellent \\
\hline 18 & $\begin{array}{l}\text { Evaluation materials in accordance with / support the } \\
\text { reach of GLO. }\end{array}$ & 4 & Excellent \\
\hline 19 & $\begin{array}{l}\text { Evaluation materials in accordance with / support the } \\
\text { reach of GLO. }\end{array}$ & 4 & Excellent \\
\hline 20 & $\begin{array}{l}\text { Evaluation materials in accordance with / support the } \\
\text { atanity of GLO indicators. }\end{array}$ & 4 & Excellent \\
\hline \multicolumn{2}{|c|}{ Total Value } & 75 & \multirow[t]{3}{*}{ Very Feasible } \\
\hline \multicolumn{2}{|c|}{ Average } & 3,75 & \\
\hline \multicolumn{2}{|c|}{ Percentage } & $93,75 \%$ & \\
\hline
\end{tabular}

Based on the assessment of the content expert as a whole the teaching material got a total score of 75 out of 20 assessment indicators with excellent criteria. Judging from the percentage of assessment results get a score of $93.75 \%$ with very decent criteria also in Very Feasible criteria.

According to the content expert, the learning module has represented every subject to be given, the module also has advantages or advantages on concise exposure through images that are very interesting for content variation, and supporting blended learning for learning assessment. Content experts also provide some criticisms and suggestions where there are no learning objectives found at the beginning of the discussion, there are still some writing errors, and some references have not been well written.

\section{Design experts and learning media}

Validation of the feasibility of Hypercontent Module Micro Teaching Course Based on Picture and Picture model conducted by design experts and learning media by assessing the learning module is divided into 
50 indicators. Design experts and learning media also provide suggestions and opinions for the improvement of learning modules. The results of the assessment of learning modules by design experts and learning media are presented in table 3 below.

Table 3. Assessment Results of Design Experts and Learning Media

\begin{tabular}{|c|c|c|c|}
\hline № & ANALYSIS ASPECTS & Value & Description \\
\hline A. & \multicolumn{2}{|l|}{ LEARNING PRESENTATION/DESIGN } & \\
\hline \multirow[t]{3}{*}{1} & \multicolumn{2}{|l|}{ Learning Objectives Formulation } & \\
\hline & a. General & 4 & Excellent \\
\hline & b. Special & 3 & Good \\
\hline \multirow[t]{3}{*}{2} & \multicolumn{2}{|l|}{ Fill order } & \\
\hline & a. Organized / systematic & 4 & Excellent \\
\hline & $\begin{array}{l}\text { b. Make it easier to learn the contents of learning } \\
\text { materials }\end{array}$ & 3 & Good \\
\hline \multirow[t]{5}{*}{3} & \multicolumn{2}{|l|}{ Description } & \\
\hline & a. Understandable & 4 & Excellent \\
\hline & b. Interesting & 3 & Good \\
\hline & c. Cause curiosity & 3 & Good \\
\hline & d. Encourage learning & 3 & Good \\
\hline \multirow[t]{5}{*}{4} & \multicolumn{2}{|l|}{ Instructions } & \\
\hline & a. Easy to understand & 4 & Excellent \\
\hline & b. Can be done & 3 & Good \\
\hline & c. Help learn the contents of learning materials & 3 & Good \\
\hline & d. Encourage to think & 3 & Good \\
\hline \multirow[t]{5}{*}{5} & \multicolumn{2}{|l|}{ Examples given } & \\
\hline & a. Clarify the subject matter & 3 & Good \\
\hline & b. Understandable & 4 & Excellent \\
\hline & c. In accordance with reality & 4 & Excellent \\
\hline & d. Inspirational & 3 & Good \\
\hline \multirow[t]{9}{*}{6} & \multicolumn{2}{|l|}{ Activity Tasks } & \\
\hline & a. Can be done & 4 & Excellent \\
\hline & b. Supporting tools & 2 & Less \\
\hline & c. Fun & 2 & Less \\
\hline & d. Increase knowledge & 3 & Good \\
\hline & e. Improving skills & 3 & Good \\
\hline & f. Develop a positive attitude & 4 & Excellent \\
\hline & g. Arousing curiosity & 3 & Good \\
\hline & h. Encourage further learning & 3 & Good \\
\hline \multirow[t]{6}{*}{7} & \multicolumn{2}{|l|}{ Evaluation/training materials/questions } & \\
\hline & a. Understandable & 3 & Good \\
\hline & b. In accordance with the subject matter & 4 & Excellent \\
\hline & c. Varies & 3 & Good \\
\hline & d. Challenging & 2 & Less \\
\hline & e. Encourage thinking & 3 & Good \\
\hline
\end{tabular}




\begin{tabular}{|c|c|c|c|}
\hline & f. Encourage further learning & 3 & Good \\
\hline & g. Workable & 4 & Excellent \\
\hline \multicolumn{2}{|c|}{ Total Value of Aspects of Presentation/Learning Design } & 100 & \multirow{3}{*}{ Very Feasible } \\
\hline \multicolumn{2}{|c|}{ Average Aspects of Presentation/Learning Design } & 3,23 & \\
\hline \multicolumn{2}{|c|}{ Percentage aspects of Presentation / Learning Design } & $80,65 \%$ & \\
\hline $\mathbf{B}$ & \multicolumn{2}{|l|}{ Grafic } & \\
\hline \multirow[t]{8}{*}{1} & \multicolumn{2}{|l|}{ Illustration in the form of an image/table/diagram } & \\
\hline & a. Clear & 4 & Excellent \\
\hline & b. Interesting & 4 & Excellent \\
\hline & c. Varies & 4 & Excellent \\
\hline & d. In accordance with ethics & 4 & Excellent \\
\hline & e. Clarify the material & 4 & Excellent \\
\hline & f. The place is close to the subject matter related to & 4 & Excellent \\
\hline & g. Understandable & 4 & Excellent \\
\hline \multirow[t]{4}{*}{2} & \multicolumn{2}{|l|}{ Display size of learning materials } & \\
\hline & a. Practical to use & 3 & Good \\
\hline & b. Display size according to & 3 & Good \\
\hline & c. Easy to use & 3 & Good \\
\hline \multirow[t]{4}{*}{3} & \multicolumn{2}{|l|}{ Layout } & \\
\hline & a. Distance between sentences/lines & 3 & Good \\
\hline & b. Comfortable reading it & 2 & Less \\
\hline & c. Consistent & 4 & Excellent \\
\hline \multirow[t]{4}{*}{4} & \multicolumn{2}{|l|}{ Letter } & \\
\hline & a. Letter size & 3 & Good \\
\hline & b. Letter form & 3 & Good \\
\hline & c. Good to read & 3 & Good \\
\hline \multirow[t]{4}{*}{4} & \multicolumn{3}{|l|}{ Color } \\
\hline & a. In accordance with reality & 3 & Good \\
\hline & b. Interesting & 4 & Excellent \\
\hline & c. Clarify the material & 4 & Excellent \\
\hline \multicolumn{2}{|c|}{ Total Graphographic Aspect Value } & 66 & \multirow[t]{3}{*}{ Very Feasible } \\
\hline \multicolumn{2}{|c|}{ Average Aspects of Graphography } & 3,47 & \\
\hline \multicolumn{2}{|c|}{ Percentage of Aspects of Graphic } & $86,84 \%$ & \\
\hline \multicolumn{2}{|c|}{ Total Value of All Aspects } & 166 & \multirow[t]{3}{*}{ Very Feasible } \\
\hline \multicolumn{2}{|c|}{ Average Total of All Aspects } & 3,53 & \\
\hline \multicolumn{2}{|c|}{ Total Percentage of All Aspects } & $83,00 \%$ & \\
\hline
\end{tabular}

Based on the assessment of design experts and instructional media as a whole the learning module got a total score of 166 out of 50 assessment indicators with very good criteria. Judging from the percentage of the assessment results get a value of $83.0 \%$ with very feasible criteria.

Design experts and instructional media also provide feedback and input where overall the learning module is neatly and comprehensively arranged, but it would be better if the use of pictures or some kind of infographic in each explanation if it becomes a key topic in the module. In addition, to maximize the use of layout designs and playing with font styles (typography) for the effectiveness of 
emphasizing the discussion. Worksheets (exercises) can have more varied types of questions / answers, not only one answer method (for example: "stuffing" only or "multiple choice" only).

\section{Linguist}

Validation of the feasibility of the Hypercontent Module for Micro Teaching Subjects based on the Picture and Picture model carried out by linguists by conducting an assessment of the learning module which is divided into 20 indicators. Linguists also provide suggestions and opinions for improving teaching materials. The results of the learning module assessment by linguists are presented in Table 4 below.

Table 4. Linguist Assessment Results

\begin{tabular}{|c|c|c|c|}
\hline № & Statement & Value & Description \\
\hline 1 & $\begin{array}{l}\text { The sentence used represents the content of the message or } \\
\text { information that you want to convey according to PUEBI }\end{array}$ & 4 & Excellent \\
\hline 2 & The sentence used is simple and direct to the target. & 4 & Excellent \\
\hline 3 & $\begin{array}{l}\text { Terms used in accordance with the Great Dictionary of The } \\
\text { Indonesian Language }\end{array}$ & 2 & Less \\
\hline 4 & The message is presented in interesting language. & 4 & Excellent \\
\hline 5 & $\begin{array}{l}\text { The message is presented clearly (does not give rise to double } \\
\text { meaning). }\end{array}$ & 4 & Excellent \\
\hline 6 & Messages are presented customarily in & 4 & Excellent \\
\hline 7 & $\begin{array}{l}\text { Words and sentences used to convey the message refer to the } \\
\text { indonesian rules, }\end{array}$ & 2 & Less \\
\hline 8 & The language used evokes pleasure when read & 4 & Excellent \\
\hline 9 & $\begin{array}{l}\text { The language used encourages students to learn the learning } \\
\text { materials thoroughly. }\end{array}$ & 3 & Good \\
\hline 10 & The language used is able to stimulate students to think critically & 3 & Good \\
\hline 11 & $\begin{array}{l}\text { The language used is able to encourage students to learn } \\
\text { independently }\end{array}$ & 3 & Good \\
\hline 12 & $\begin{array}{l}\text { Language used in accordance with the level of intellectual } \\
\text { development of students }\end{array}$ & 3 & Good \\
\hline 13 & $\begin{array}{l}\text { Language used according to student's level of emotional } \\
\text { development }\end{array}$ & 4 & Excellent \\
\hline 14 & $\begin{array}{l}\text { The delivery of messages between one unit and an adjacent unit } \\
\text { reflects a logical relationship. }\end{array}$ & 4 & Excellent \\
\hline 15 & $\begin{array}{l}\text { The delivery of inter subunit messages in one unit reflects a logical } \\
\text { relationship. }\end{array}$ & 4 & Excellent \\
\hline 16 & $\begin{array}{l}\text { The delivery of messages between adjacent para paragraphs reflects } \\
\text { logical relationships. }\end{array}$ & 4 & Excellent \\
\hline 17 & The delivery between the paragraphs reflects a logical relationship. & 4 & Excellent \\
\hline 18 & Terms used for precise meaning & 4 & Excellent \\
\hline 19 & Terms used consistently & 4 & Excellent \\
\hline 20 & $\begin{array}{l}\text { Consistent depiction of symbols or icons between sections in } \\
\text { learning materials }\end{array}$ & 4 & Excellent \\
\hline \multicolumn{2}{|r|}{ Total Value } & 72 & \multirow[t]{3}{*}{ Very Feasible } \\
\hline \multicolumn{2}{|c|}{ Average } & 3,60 & \\
\hline \multicolumn{2}{|c|}{ Percentage } & $90,00 \%$ & \\
\hline
\end{tabular}


Based on the linguist's assessment as a whole the learning module got a total score of 72 out of 20 assessment indicators with very good criteria. Judging from the percentage of the assessment results get a value of $90.0 \%$ with very feasible criteria.

The linguist gave a response that overall the learning module was feasible and could be used as a reference in learning the micro teaching course. The learning module also has advantages or advantages where the learning is more contextual, has applied technology in learning activities, and displays learning activities with the help of image media. Some suggestions from linguists are that some of the languages used are still a lot of mistakes, firstly placing the conjunctive word at the beginning of the sentence, secondly there are still many typing errors, the third writing of borrowed or foreign words is still a lot of mistakes, the fourth paragraph layout is still not good, in one Paragraphs must consist of 4 lines and one unit of meaning, while in modules there are paragraphs consisting of three lines. A summary of the results of the one to one trial with 3 experts is presented in Table 5 below.

Table 5.One to One Test Results by Experts

\begin{tabular}{|l|l|l|l|l|l|l|}
\hline №. & Expert & Amount & $\begin{array}{l}\text { Theoretical } \\
\text { Maximum } \\
\text { Score }\end{array}$ & $\begin{array}{l}\text { Empirical } \\
\text { Score }\end{array}$ & Percentage & Interpretation \\
\hline 1 & Content & 20 & 80 & 75 & 93,75 & Very Feasible \\
\hline 2 & $\begin{array}{l}\text { Learning } \\
\text { Design and } \\
\text { Media }\end{array}$ & 50 & 200 & 166 & 83,00 & Very Feasible \\
\hline 3 & Language & 20 & 80 & 72 & 90,00 & Very Feasible \\
\hline Amount & 90 & 360 & 313 & & \\
\hline Average & $\mathbf{2 4 , 6 7}$ & $\mathbf{1 2 0}$ & $\mathbf{1 0 4 , 3 3}$ & $\mathbf{8 8 , 9 2}$ & Very Feasible \\
\hline
\end{tabular}

Based on Table 5, it can be seen that the feasibility percentage of the hypercontent module of the micro teaching course based on the picture and picture model according to content experts is $93.75 \%$, according to design and learning media experts is $83 \%$, and according to language experts is $90 \%$. If interpreted, the feasibility percentage of the hypercontent module in the micro teaching course based on the picture and picture model is classified as very feasible. Overall, the feasibility percentage of the hypercontent module of the micro teaching course based on the picture and picture model according to the expert was $88.92 \%$ which was classified as very feasible.

\section{Implementation Stage}

The implementation stage is an activity of implementing the previously developed teaching material design. The implementation stage of the modules developed in this study is to learn together with a student with special need. At the end of the lesson, a student with special need was asked to evaluate the module that had been developed by filling out a questionnaire. The results of the assessment of the learning module by a student with special need are presented in Table 6 below.

Table 6. Student Assessment Results

\begin{tabular}{|c|c|c|c|}
\hline № & ANALYSIS ASPECTS & Value & Description \\
\hline A. & \multicolumn{3}{|l|}{ LEARNING PRESENTATION/DESIGN } \\
\hline \multirow[t]{3}{*}{1} & \multicolumn{3}{|l|}{ Fill order } \\
\hline & a. Organized/systematic & 4 & Excellent \\
\hline & $\begin{array}{l}\text { b. Make it easy to learn the contents of the } \\
\text { module }\end{array}$ & 4 & Excellent \\
\hline \multirow[t]{5}{*}{2} & \multicolumn{3}{|l|}{ Description } \\
\hline & a. Understandable & 4 & Excellent \\
\hline & b. Interesting & 4 & Excellent \\
\hline & c. Cause curiosity & 4 & Excellent \\
\hline & d. Encourage learning & 4 & Excellent \\
\hline \multirow[t]{2}{*}{3} & \multicolumn{3}{|l|}{ Instructions } \\
\hline & a. Easy to understand & 4 & Excellent \\
\hline
\end{tabular}




\begin{tabular}{|c|c|c|c|}
\hline & b. Can be done & 4 & Excellent \\
\hline & c. Help learn the contents of the module & 4 & Excellent \\
\hline & d. Encourage to think & 4 & Excellent \\
\hline \multirow[t]{5}{*}{4} & \multicolumn{3}{|l|}{ Examples given } \\
\hline & a. Clarify the material & 4 & Excellent \\
\hline & b. Understandable/understandable & 4 & Excellent \\
\hline & c. In accordance with reality & 4 & Excellent \\
\hline & d. Inspirational & 4 & Excellent \\
\hline \multirow[t]{9}{*}{5} & \multicolumn{3}{|l|}{ Activity Tasks } \\
\hline & a. Can be done & 4 & Excellent \\
\hline & b. Support tools & 4 & Excellent \\
\hline & c. Fun & 4 & Excellent \\
\hline & d. Increase knowledge & 4 & Excellent \\
\hline & e. Improve skills & 4 & Excellent \\
\hline & f. Develop a positive attitude & 4 & Excellent \\
\hline & g. Arousing curiosity & 4 & Excellent \\
\hline & h. Encourage further learning & 4 & Excellent \\
\hline \multirow[t]{8}{*}{6} & \multicolumn{3}{|l|}{ Evaluation/training materials/questions } \\
\hline & A. Understandable & 4 & Excellent \\
\hline & B. In accordance with the subject matter & 3 & Good \\
\hline & c. Varies & 3 & Good \\
\hline & d. Challenging & 3 & Good \\
\hline & E. Encouraging thinking & 3 & Good \\
\hline & F. Encourage further learning & 3 & Good \\
\hline & G. Workable & 4 & Excellent \\
\hline \multicolumn{2}{|c|}{$\begin{array}{l}\text { Total Value of Aspects of Presentation/Learning } \\
\text { Design }\end{array}$} & 111 & \multirow[t]{3}{*}{ Very Feasible } \\
\hline \multicolumn{2}{|c|}{ Average Aspects of Presentation/Learning Design } & 3,828 & \\
\hline \multicolumn{2}{|c|}{ Percentage aspects of Presentation / Learning Design } & $95,69 \%$ & \\
\hline B. & \multicolumn{3}{|l|}{ Language } \\
\hline \multirow[t]{4}{*}{1} & \multicolumn{3}{|l|}{ Use of language rules } \\
\hline & a. Spelling (PUEBI) & 4 & Excellent \\
\hline & b. Sentence structure (SPO) & 4 & Excellent \\
\hline & c. Punctuation & 4 & Excellent \\
\hline \multirow[t]{4}{*}{2} & Words & & \\
\hline & a. There are difficult words & 4 & Excellent \\
\hline & b. Polite & 4 & Excellent \\
\hline & c. Understandable & 4 & Excellent \\
\hline \multirow[t]{4}{*}{3} & Sentence & & \\
\hline & a. sentence length & 3 & Good \\
\hline & b. inter-group relationships & 3 & Good \\
\hline & c. understandable & 3 & Good \\
\hline 4 & Paragraph & & \\
\hline
\end{tabular}




\begin{tabular}{|c|c|c|c|}
\hline & a. Paragraph length & 4 & Excellent \\
\hline & b. Interparagraph relationships & 4 & Excellent \\
\hline \multirow[t]{3}{*}{5} & Language style & & \\
\hline & a. Help understand the subject matter & 4 & Excellent \\
\hline & b. Encourage further reading & 4 & Excellent \\
\hline \multicolumn{2}{|c|}{ Total Language Aspect Value } & 49,00 & \multirow[t]{3}{*}{ Very Feasible } \\
\hline \multicolumn{2}{|c|}{ Average Aspects of Language } & 3,77 & \\
\hline \multicolumn{2}{|c|}{ Percentage of Language Aspects } & $94,23 \%$ & \\
\hline C. & \multicolumn{3}{|l|}{ Grafic } \\
\hline \multirow[t]{8}{*}{1} & \multicolumn{3}{|c|}{ Illustration in the form of an image/table/diagram } \\
\hline & a. Clear & 4 & Excellent \\
\hline & b. Interesting & 4 & Excellent \\
\hline & c. Varies & 3 & Good \\
\hline & d. In accordance with ethics & 3 & Good \\
\hline & e. Clarify the material & 4 & Excellent \\
\hline & f. The place is close to the related subject & 4 & Excellent \\
\hline & g. Understandable & 4 & Excellent \\
\hline \multirow[t]{4}{*}{2} & \multicolumn{3}{|l|}{ Layout } \\
\hline & a. Distance between sentences/lines & 4 & Excellent \\
\hline & b. Comfortable reading it & 4 & Excellent \\
\hline & c. Consistent & 4 & Excellent \\
\hline \multirow[t]{4}{*}{3} & \multicolumn{3}{|l|}{ Letter } \\
\hline & a. Font size & 4 & Excellent \\
\hline & b. Letter shape & 4 & Excellent \\
\hline & c. Good to read & 4 & Excellent \\
\hline \multirow[t]{4}{*}{4} & \multicolumn{3}{|l|}{ Color } \\
\hline & a. In keeping with reality & 4 & Excellent \\
\hline & b. Interesting & 4 & Excellent \\
\hline & c. Clarify the material & 4 & Excellent \\
\hline \multicolumn{2}{|c|}{ Total Language Aspect Value } & 62 & \multirow[t]{3}{*}{ Very Feasible } \\
\hline \multicolumn{2}{|c|}{ Average Aspects of Language } & 3,88 & \\
\hline \multicolumn{2}{|c|}{ Percentage of Language Aspects } & $96,88 \%$ & \\
\hline \multicolumn{2}{|c|}{ Total Value of All Aspects } & 222 & \multirow[t]{3}{*}{ Very Feasible } \\
\hline \multicolumn{2}{|c|}{ Average Total Of All Aspects } & 3,83 & \\
\hline \multicolumn{2}{|c|}{ Total Percentage of All Aspects } & $95,69 \%$ & \\
\hline
\end{tabular}

Based on the MBK assessment as a whole the learning module received a total score of 222 out of 58 assessment indicators with very good criteria. Judging from the percentage of the assessment results get a value of $95.69 \%$ with very decent criteria.

\section{CONCLUSION}

The results from this research are: (1) Hypercontent Micro Teaching module with a picture and picture model; (2) Result development of a learning module for the Micro Teaching subject uses the ADDIE model 
includes the stages of analysis, design, development, implementation, and evaluation. (3) The results for the trial with based on the picture and picture model according to content experts was $93.75 \%$, according to design and learning media experts was $83 \%$, and according to language experts was $90 \%$. Overall, the feasibility percentage of the hypercontent module in the Micro Teaching based on the picture and picture model according to the experts is $88.92 \%$ which is classified as very feasible category. (4) The results of the implementation with Students with spesial needs is $95.69 \%$ with very feasible criteria.

\section{REFERENCES}

Ainin Pradina, Y., \& Dwi Hastuti, W. (2017). The Effect of Picture and Picture Learning Model towards Science Outcomes for Students with Hearing Impairment in the Class VII. Journal of ICSAR, 1 (2), 145-149. http://dx.doi.org/10.17977/um005v1i22017p145.

Branch, R. M. (2009). Instructional design: The ADDIE approach. New York: Springer.

Cahyadi, R. (2019). Addie Model Based Teaching Materials Development. Halaqa: Islamic Education Journal, 3 (1), 35-42. doi: http: //doi.org/10.21070/halaqa.v3i1.2124

Milman, N. B., \& Kilbane, C.R. (2013). Teaching models: Designing instruction for 21st century learners. New York, NY: Pearson.

Muhyidin Nurzaelani, M., Septiani, M., \& Maimunah, M. (2020). Design of Electronic Learning Materials Based on Higher Order Thinking Skills (HOTs) in the Capita Selecta Subject of Research Results. JTP - Journal of Educational Technology, 22 (1), 71-81. https://doi.org/10.21009/jtp.v22i1.15530.

Ngalimun. (2016). Learning Strategies and Models. Yogyakarta: Aswaja Pressindo.

Tegeh, I., Jampel, I., \& Pudjawan, K. (2015). Development of a Development Research Model Textbook with the ADDIE Model. National Seminar on Innovative Research, 3.

Retrieved from https://eproceeding.undiksha.ac.id/index.php/senari/article/view/507

Permenristek Dikti Number 46 of 2017 concerning Special Education and Special Services in Higher Education.

Suprijono, A. (2009). Cooperative Learning. Yogyakarta: Student Library.

Law Number 8 of 2016 concerning Persons with Disabilities.

Tinneke E. M. Sumual, Pengaruh Kompetensi Kepemimpinan, Budaya Organisasi terhadap Kinerja Pegawai di Universitas Negeri Manado, Mimbar Vol. 31, N0. 1, 2015,h. 73

Peraturan Menteri Agama Republik Indonesia No I6 tahun 2010 pasal 16, h. 9-10 Http://Pendis kemenag.co.id, diakses 30 Januari Pukul 09;30

Asmaun Sahlan, Mewujudkan Budaya Religius di Sekolah (Upaya Mengembangkan PAI dari Teori ke Aksi, Malang: UIN Maliki Press, 2009, hal. 75

Makherus Sholeh, Pendidikan Karakter Melalui Implementasi Buda Religius di Sekolah (Studi di SD LPI Zamrotus Salamah Tulungagung), Jurnal Ilmiah PGMI. Vol. VI, N0. 01, 2016, h. 131

Daryanto. 2014. Pendekatan Pembelajaran Saintifik Kurikulum 2013. Yogyakarta: Penerbit Gava Media.

Ni Nyoman Padmadewi dkk, Pengantar Microteaching, Depok : PT. RAJAGRAFINDO PERSADA, 2017.

Uzer Usman, Menjadi Guru Profesional, Bandung : Rosda Karya, 2017.

Syafrudin Nurdin \& Adriantoni, Kurikulum dan Pembelajaran, Jakarta:Rajagrafindo, 2016.

Ridwan Abdullah Sani, Penilian Autentik, Jakarta: Bumi Aksara, 2016.

Abuddin Nata, Pengembangan Profesi Keguruan dalam Perspektif Islam, Depok: Rajawali Press, 2019.

Syafruddin Nurdin dkk, Profesi Keguruan, depok: Rajawali Press, 2019

Maemunah Sa'diyah, Budaya Akademik Guru Madrasah, Bogor: UIKA Press, 2017

Nurfuadi, Profesionalisme Guru, Purwokwerto: Stain Press, 2012

Jejen Musfah, Peningkatan Kompetensi Guru, Jakarta: Kencana, 2011

Rusman, Model-model Pembelajaran, Jakarta: RajaGrafindo Persada, 2011 Asli 12)Menganalisa kemampuan mengajar yang telah dimilikinya; dan 